\title{
CANDID SCIENCE
}

\section{Conversations with Famous Chemists}


This page is intentionally left blank 


\section{CANDID SCIENCE}

Conversations with Famous Chemists

\section{István Hargittai}

Edited by Magdolna Hargittai 


\author{
Published by \\ Imperial College Press \\ 57 Shelton Street \\ Covent Garden \\ London WC2H 9HE
}

Distributed by

World Scientific Publishing Co. Pte. Ltd.

5 Toh Tuck Link, Singapore 596224

USA office: Suite 202, 1060 Main Street, River Edge, NJ 07661

UK office: 57 Shelton Street, Covent Garden, London WC2H 9HE

\author{
István Hargittai \\ Budapest University of Technology and Economics \\ Eötvös University and Hungarian Academy of Sciences \\ H-1521 Budapest, Hungary \\ Magdolna Hargittai \\ Eötvös University and Hungarian Academy of Sciences \\ H-1518 Budapest, Pf. 32, Hungary
}

\title{
British Library Cataloguing-in-Publication Data
}

A catalogue record for this book is available from the British Library.

First published 2000

Reprinted 2002

\section{CANDID SCIENCE \\ Conversations with Famous Chemists}

Copyright $\odot 2000$ by István Hargittai

All rights reserved. This book, or parts thereof, may not be reproduced in any form or by any means, electronic or mechanical, including photocopying, recording or any information storage and retrieval system now known or to be invented, without written permission from the Publisher.

For photocopying of material in this volume, please pay a copying fee through the Copyright Clearance Center, Inc., 222 Rosewood Drive, Danvers, MA 01923, USA. In this case permission to photocopy is not required from the publisher.

ISBN 1-86094-151-6

ISBN 1-86094-228-8 (pbk) 


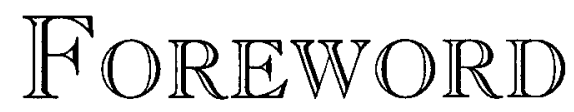

This collection of interviews by Professor Hargittai is a timely celebration of the remarkable century of chemistry, which has just passed. Those interviewed are some forty chemists, who were fortunate enough to live during the momentous developments in chemistry, which have occurred during the last decades of the millennium.

These historic events will be retold for centuries to come, often with more understanding and appreciation than we can have today. But, in one respect, what is written here will never be repeated because it is the personal experiences of the chemists who took part, each of them a unique individual.

Scientists are sometimes seen as automata without human feeling or sentiment (unlike artists for example!). The scientists themselves, and those who live with scientists, know how false this view is. But, unfortunately, most people know very little of science or scientists personally and often see them as living in a different world from "ordinary" people.

I hope that the interviews recorded here will do something to dispel this increasing divide in our understanding. They tell how chemists of today have lived and worked, why they chose chemistry as a career and how they were led to make the discoveries for which they are best known. The informality of the interviews gives the impression that one is sharing in a conversation rather than listening to an autobiographical lecture.

Children are born scientists but, if they are to retain their love of science, they need role models to follow and encouragement from those who have been successful. This book will be enjoyed by all who have some interest in science and it will be of special value to the young people whom it may encourage to follow those, whose stories are told here. 
This page is intentionally left blank 


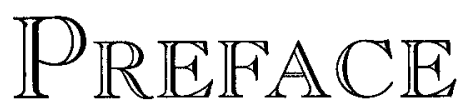

At the dawn of the twenty-first century and the new millennium, it is fascinating to review the achievements of chemistry during the past decades of the twentieth century, so extraordinary in scientific progress. It is also fascinating to get acquainted with the stories behind these achievements directly from some of their most important participants. The subject matter in this collection of interviews covers a broad range of chemistry, with emphasis on the following loosely identified areas: structural chemistry, medicinal chemistry, natural products chemistry, stereochemistry, theoretical and computational chemistry, inorganic chemistry, physical organic chemistry, NMR spectroscopy, fullerenes, kinetics and reaction mechanisms, atmospheric chemistry. There is, of course, considerable overlap between these areas, and even more so in the research activities of most of the scientists interviewed. There are also important missing fields. Future collections, already under preparation, will considerably expand the scope of this volume.

This volume contains the first selection of my conversations with famous scientists. In addition to the interviews, we present here a few auxiliary entries. They include a brief chapter on Odd Hassel to whom I never posed questions in the way I did to the others, but my interactions with him made me think about him as one of my interviewees. I prepared two auxiliary entries of quotations by Erwin Chargaff and John Cornforth to augment their interviews. I did this because I wanted to share the intellectual pleasures I have experienced from their writings. Another entry augments the brief interview with Linus Pauling. It is about the controversy of the resonance theory in the Soviet Union at the beginning of the 1950s. I 
attended the Pauling memorial session of the ACS meeting in 1994 in Anaheim and was surprised by the scarce knowledge of this story among our colleagues who have been interested in Linus Pauling's life and works. Yet another entry is on the beginnings of the multiple metal-metal bond studies. The relevant systems were produced and examined by scientists in Moscow, although the multiple bonds in them were not recognized until Albert Cotton's studies. I compiled a brief segment on Buckminster Fuller because of his conspicuous, if indirect, role in the fullerene story. This was greatly helped by a conversation I had recorded with Ed Applewhite, Fuller's assistant in creating his opus magnum, Synergetics. Finally, there is a brief entry on Paul de Kruif because his book, Microbe Hunters, was at least as important as the chemistry set in turning interested children's attention to chemistry for the generations that are so prominently represented among my interviewees.

Although my first conversation with a famous chemist, Nikolai Semenov, was recorded back in 1965, launching the quarterly magazine, The Chemical Intelligencer by Springer-Verlag, New York in 1995 gave a great incentive for these conversations. I am grateful to Springer-Verlag for their gracious permission to reproduce published material here from The Chemical Intelligencer. Some interviews are reproduced in full, others with some changes, saving some space or extending the description of the circumstances of the interview. Quite a few of the interviews are presented for the first time in this volume. The relevant bibliographical data are given in each respective entry.

The general procedure of preparing an interview is the following. I contact the interviewee, we set up a date for our meeting, and have a fairly loose conversation recorded on audiotape. I then prepare and slightly edit the transcripts and send them to the interviewee for correction, deletion, and addition. This procedure is repeated until the interviewee feels absolutely comfortable with the material. Before publication, there is usually some additional light copyediting. The conversations are illustrated with snapshots made during the conversation and by photos provided by the interviewee. In a few cases, the interview was by correspondence.

In all the conversations I am trying to bring out some important aspects of chemistry as well as to learn about the life and thoughts of the interviewee. Since I am a fellow scientist rather than an investigative reporter, I never try to go after a particular problem with which the interviewee seems uncomfortable. From the start of our conversation I am asking my interviewee to ignore any of my questions that he or she does not care to discuss. 
Thus the reader may at places feel that I should have pressed for more answers or more details and would never learn about my unanswered questions: I may and then, I may not have asked that particular question. My approach has limitations in this respect. On the other hand, I see benefit in my approach in that the interviewee may open up more to a friendly colleague than to an investigative reporter. In any case, the purpose of the interviews was to learn about chemistry and bring great scientists in human proximity. I have myself learned a great deal from these conversations, in terms of both chemistry and human behavior and personal philosophy. I am grateful to all my interviewees for their time, their contribution, and for their interest in and support for the project.

This book was edited by Magdolna Hargittai, herself a chemistry Ph.D. and Research Professor, who is my partner in my ventures in chemistry and all other aspects of my life, and who often knows my emphases and preferences before I could even articulate them.

For my doctoral work I did not have a supervisor, not even in a formal way. I never liked authority. Yet I always felt blessed when I had a good teacher and somehow I always had one at the right moment, although not necessarily in physical proximity. Having good teachers is the greatest thing that can happen in one's career. A good teacher need not be appointed to be your teacher; a good teacher is a good example, and that may come in a great variety of ways. I feel that my interviews have given me another experience of benefiting from good teaching, and my greatest hope is that they will be received as such by my readers, too. It is in this sense that I would like to dedicate this volume to the coming generations of students, for whom much of the material presented here will be science history. 
This page is intentionally left blank 


\section{CONTENTS}

Foreword $\quad$ v

Preface vii

Linus Pauling $\quad 2$

The Great Soviet Resonance Controversy $\quad 8$

$\begin{array}{ll}\text { Erwin Chargaff } & 14\end{array}$

Quotable Chargaff $\quad 29$

Frank H. Westheimer $\quad 38$

Gertrude B. Elion $\quad 54$

$\begin{array}{ll}\text { Carl Djerassi } & 72\end{array}$

Paul J. Scheuer $\quad 92$

$\begin{array}{ll}\text { Ayhan Ulubelen } & 114\end{array}$

John W. Cornforth $\quad 122$

Quotable Cornforth $\quad 135$

$\begin{array}{ll}\text { Vladimir Prelog } & 138\end{array}$

$\begin{array}{ll}\text { Derek H. R. Barton } & 148\end{array}$

$\begin{array}{ll}\text { Odd Hassel } & 158\end{array}$

Michael J. S. Dewar 164

$\begin{array}{ll}\text { John A. Pople } & 178\end{array}$ 
xii Hargittai, Candid Science

Roald Hoffmann 190

$\begin{array}{ll}\text { Kenichi Fukui } & 210\end{array}$

Milton Orchin $\quad 222$

F. Albert Cotton $\quad 230$

The Beginnings of Multiple Metal-Metal Bonds 246

$\begin{array}{ll}\text { Herbert C. Brown } & 250\end{array}$

$\begin{array}{ll}\text { George A. Olah } & 270\end{array}$

John D. Roberts 284

Richard R. Ernst $\quad 294$

$\begin{array}{ll}\text { Eiji Osawa } & 308\end{array}$

Elena G. Gal'pern and Ivan V. Stankevich 322

Harold W. Kroto 332

The Fuller Connection $\quad 358$

Richard E. Smalley $\quad 362$

Robert F. Curl $\quad 374$

Wolfgang Krätschmer $\quad 388$

Robert L. Whetten $\quad 404$

Philip E. Eaton $\quad 416$

R. Stephen Berry $\quad 422$

What Turned You to Chemistry? 436

Kenneth S. Pitzer $\quad 438$

F. Sherwood Rowland $\quad 448$

Nikolai N. Semenov 466

George Porter $\quad 476$

Ahmed H. Zewail $\quad 488$

Name Index $\quad 509$ 